\title{
Open access repository for the brazilian literature on agroecology ${ }^{1}$
}

\author{
Maria de Cléofas Faggion Alencar \\ Pós-doutora em Informação para Negócios pela School of Library \& Information Science/Kent State University \\ Analista III da Embrapa Meio Ambiente \\ E-mail: cleo@cnpma.embrapa.br
}

\begin{abstract}
The Brazilian technical and scientific literature on Agroecology is plentiful, is scattered and of difficult access and the hypothesis is that the knowledge of the area was produced but is composed by a knowledge to be organized. These features are barriers and constrains for farmers to use agricultural information as well as for providers of extension services to meet information needs of farmers. In this direction there is a consensus among researchers who study the information that the adequate alternative and adopted in the entire world are the open access digital repositories. Besides taking into account all essential actions to manage technical and scientific information, the open access digital repositories contribute to better communication process of Science. This occurs because such tools create necessary conditions to researchers to have timely, quickly, easy and perpetual access to the information they need to develop their activities. Also help to disseminate the results and provide increase on citation, researcher and institution visibility. A digital repository can be institutional or by topic where the institutional manages and fosters the scientific production of the institution as a whole. Repositories by topic make evident the stage of development of a scientific community. The objective is to describe how the collection of journal and magazines articles, conference papers, documents published by NGOs, government papers, dissertations and thesis, documents on the Internet, agricultural research produced by institutes and universities, etc. will be redeem to create and manage an open access digital repository of the Brazilian bibliographic production on Agroecology host by the Organic Eprints.
\end{abstract}

\section{Problem Statement}

The reduction of time between knowledge and technology production to society has been a problem for all sectors. The constitution of validation networks bring about results for systematic technology transfer and the development of agribusiness in all places.

The Brazilian Agricultural Research Corporation (Embrapa) contributes to this purpose with actions of:

- New strategies of technology transfer with corporative projects organized by national or regional issues and on production chain;

- Stimulation and articulation of structured projects of technology transfer to family farms and traditional communities by unit and/or region to promote the territorial development;

\footnotetext{
${ }^{1}$ Texto apresentado à $76^{\circ}$ Conferencia Geral da Federação Internacional de Associações de Bibliotecas (IFLA) na Suécia, ago 2010, no tema da conferência: "Open access to knowledge - promoting sustainable progress".
}

InCID: R. Ci. Inf. e Doc., Ribeirão Preto, v. 1, n. 2, p. 153-160, jul./dez. 2010. 
- Technology transfer (TT) on national and international levels by cooperation agenda.

Also, Embrapa promotes the intra and inter institutional articulation to the establishment of technology transfer networks to strengthen new institutional solutions to public and private sector, to speed up the process of results accessibility to the Brazilian and international markets.

The world celebrates mores than 30 years of Agroecology where Brazil has being an active actor in all conceptions: Science, movement and practices and Embrapa has been carrying out activities to enhance agricultural research. Being a world reference institution for a long time, Embrapa reacts for paradigms changes on issues about land use, social order and the market. Considering the natural resources preservation and food security, in 2006 Embrapa published The Agroecological Reference Milestone.

The history of Agroecology was discussed by Wezel et al. (2009) including the terminology being used from case studies about USA, Brazil, Germany and France. The expansion of the scientific discipline changed radically from agroecosystems to all food system as a global network of production, distribution and consumers.

The Agroecological Refernce Milestone (2006) consolidated one of institutional strategies to approach Agroecology and Organic Agriculture. Also, gave funds for two national projects (Scientific and Technical Foundation to the Development of Brazilian Organic Agriculture (http://www.macroprograma1.cnptia.embrapa.br/agriorg) and Agroecological Transition at (http://www.macroprograma1.cnptia.embrapa.br/agroecologia) and carry out actions as:

The Embrapa Information Agency, Production Systems, Rural Talk, Embrapa Digital Videoteca, Mini-Libraries and its Database on Family Agriculture through The Data Base of Agricultural Research - BDPA. All at www.embrapa.br.

The application of ecology in agriculture is considered global reference to agricultural sustainability and of the food production systems. It has been reviewed with the purpose to find alternatives for problems identified, to fulfill possible gaps and to support a sustainable world (WEZEL; SOLDAT, 2009; LAMINE; BELLON, 2009; WEZEL et al., 2009).

Brazil has a considerable number of organic system producers and still much of the technical-scientific production has very little international acknowledge. The literature publish in the country has a unique feature which must be treated otherwise its status will 
continue invisible to the world. Most of this literature is published under Agroecology terminology and it is not indexed. Because of this and for purposes of this paper the word Agroecology will be used.

A survey on international databases with the following strategic search "agroecology" and (brazil or brasil) since the terminology is consistent with use in Brazil. Table 1 shows the results.

TABLE 1 - Search “agroecology” and (brazil or brasil)

\begin{tabular}{|c|c|c|c|}
\hline Database & Type & \# Agroecology & \# (Brazil or Brasil) \\
\hline Web of Science & Multidisciplinary & 218 & 16 \\
\hline Scopus & Multidisciplinary & 565 & 19 \\
\hline SciFinder & Chemistry & 337 & 3 \\
\hline
\end{tabular}

The Brazilian pos-graduate system Qualis/CAPES registered 46 serials titles on agriculture where only ten of these titles have Impact Factor as follow:

Brazilian archives of biology and technology -0.353

Genetics and Molecular Biology - 0.576

Iheringia. Série Zoologia - 0.194

Neotrópica Entomology - 0.460

Pesquisa Agropecuária Brasileira - 0.645

Pesquisa Veterinária Brasileira - 0.425

Revista Brasileira de Zootecnia - 0.463

Revista Brasileira de Zoologia - 0.403

Revista Brasileira de Ciência do Solo - 0.660

Scientia Agrícola - 0.700

Also, none of them focusing Organic Agriculture or Agroecology. But outside this set, The Associação Brasileira de Agroecologia publishes the Revista Brasileira de Agroecologia and the journal Revista Agriculturas: Experiências em Agroecologia is the brazilian edition of LEISA. Both titles are very important on reports of experiences it is largely used among researchers. 
For a science under development it is known that it is important to consider all kinds of scientific communication, all types of materials and intellectual production niches. In this case, the gray literature on Agroecology is relevant.

In Brazil, there are an enormous amount of papers classified as Grey/Gray Literature. The term is used by the intelligence community, librarians, and medical and research professionals to refer to a body of materials that cannot be found easily through conventional channels such as publishers, "but which is frequently original and usually recent" (DEBACHERE, 1995). Examples are: technical reports from government agencies or scientific research groups, working papers from research groups or committees, white papers, or preprints.

During 2009, a survey for Brazilian Agroecology was initiated and the collection founded was classified as conferences short papers or abstracts, dissertations and thesis and journal articles. All documents are on digital format and spread on the Internet (Table 2).

TABLE 2 - Type of document and collection

\begin{tabular}{|l|l|}
\hline Type of document & $\#$ \\
\hline Events (congress, seminars) & 2391 \\
\hline Dissertation and thesis & 42 \\
\hline Articles/Revista Agriculturas & 243 \\
\hline Articles/ Revista Brasileira de Agroecologia & 51 \\
\hline TOTAL & 2727 \\
\hline
\end{tabular}

Although there are problems related to the value of this literature, a trial was performed and it was possible to develop two studies to explore the collection, one about the agriculture conventionalization and the other about gender (ABREU; BELLON; ALENCAR, 2009; ALENCAR; ABREU, 2009). Also tests were done to verify the frequency of certain subjects, for example, on the serial Revista Agriculturas, very high rate was found for crop management, biological control, consumers and market.

The hypothesis formulated here is that the knowledge was developed but has to be systematize and disseminate because the Brazilian Agroecology Literature is rich, scatter and hard to find.

It is consensual among information researchers that the alternative is the digital repository with open access. Considering all management information process of technical and scientific information, the digital repositories of open access support better 
communication on Science. These tools produce ideal conditions to researchers because of its rapid and ease access, and most important, everlasting access to information to support research development and results dissemination which also encourage citation, visibility to researcher and its institution and science status.

The repositories can be institutional or by topic where the institutional repositories manages and promotes visibility to the scientific production and the repositories by topic make evident the stage of development of the scientific communities. Embrapa developed its own repository called Infoteca (BDPA http://www.infoteca.cnptia.embrapa.br/) with technical publication of its employees, its memory of technical production. Also, using the technology Protocol Metadata Harvesting the new interface of Database of Agricultural Research (http://www.bdpa.cnptia.embrapa.br/) will be collecting from other repositories when appropriate to its users. The experiences already began and figure 1 shows the functioning of the collector.

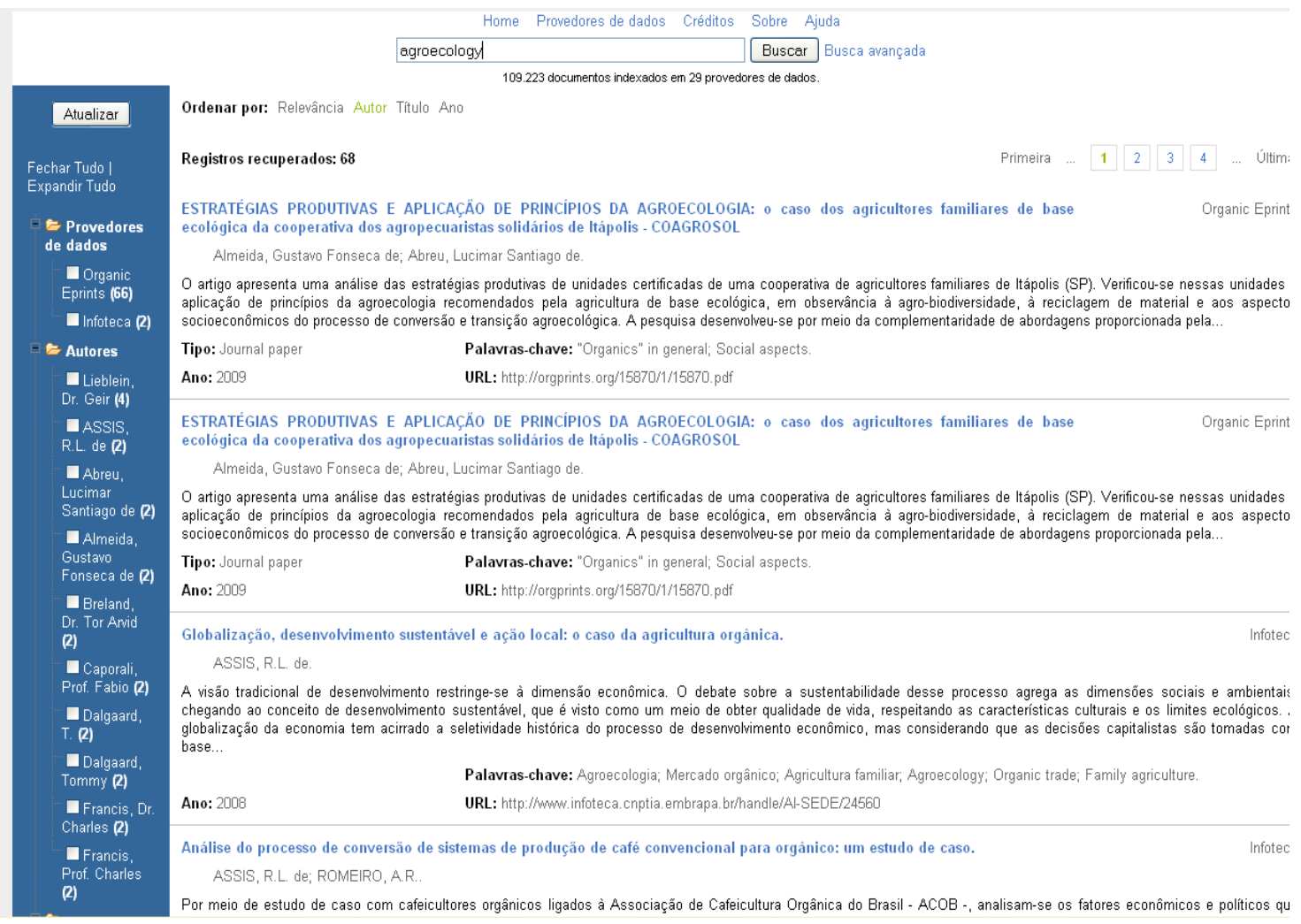

FIGURA 1 - Test with Protocol Metadata Harvester searching on Organic Eprints

The purpose of this project is to generate and manage a digital repository of open access for the Brazilian Literature on Agroecology focusing Grey/Gray Literature using the Organic Eprints as a host which is the international open access archive for papers related to 
research on organic agriculture. The Organic Eprints contains full-text papers in electronic form together with full bibliographic information, abstracts and other metadata.

Considering the presence on the Internet of a international repository of open access for the bibliographic production of organic agriculture and agroecology on its full operation on: http://orgprints.org/, it has been chosed to host the repository of this project. Organic Eprints is available through The International Centre for Research in Organic Food Systems (ICROFS) ans its partners.

The ICROFS (http://www.icrofs.org/index.html) was founded in 2008 as a expanded research center to the old Danish Agricultural Research Centre for Organic Farming (DARCOF) which the Denmark Government decided to provide with a international counsil. The Organic Eprints provide access to electronic documents and has cooperation with many countries.

Copyright rules is provided by Organic Eprints and Embrapa which will be follow integraly as on:

Embrapa Environment Manual of the Local Council of Publication

http://www.cnpma.embrapa.br/intranet/cp_norma_autor.html

Embrapa's Editorial Manual

http://manual.sct.embrapa.br/editorial/default.jsp

Copyright Issues e PoPolicy-Background and Support-Open Access-Copyright issuesStatistics-Software and Development

http://orgprints.org/about.html.

The open access repository of the brazilian bibliographic production on Agroecology to be registered on Organic Eprints will have home page and all options of the menu in Portuguese language which are: About, Browse, Search, Latest and Help. The establishment of the repository of Brazilian literature on Agroecology and organic agriculture come about to fill a necessity among researchers and technology transfer agents to face the new paradigms of scientific communication, the management of bibliographic production of the area and its development because needs systematization and dissemination.

The project also intend to validate the use of information of the repository and collaborate with discussion on realignment of activities of Technology Transfers on Embrapa 
through identification of new methodologies of Technology Transfers to strengthen institutional solutions to Embrapa and its partners.

It is all known that Information Science also can contribute with bibliometric studies that explore a body of documents related to its authors, institutions, terminologies features as to achieve quality on public policies which will improve producers development and bring the literature to it's mainstream. It is scheduled the development of bibliometric studies of the body of the repository as well the continuation of gender studies.

The elements of the project are:

1. Documents and information of brazilian bibliographic production on Agroecology and Organic Agriculture;

2. Organic Eprints;

3. Reserchers and producers of information and documents on the area;

4. Bibliometry; and,

5. Gender Studies.

It is important to enhance that subject repositories of open access do not have the purpose to replace the traditional ways of scientific publication but considers the management of technical and scientific information and produces alternative communication channels to promote the decrease of the time between the publication of new scientific discoveries, its use and a better process of Technology Transfer.

\section{References}

ABREU, L. S.; BELLON, S.; ALENCAR, M. de C. F. 2009. Brazilian multifaceted ecologically-based agriculture: between conventionalization and agroecological principles application. In: EUROPEAN SOCIETY FOR RURAL SOCIOLOGY CONGRESS, 23., 2009. Conference papers... Vaasa: Finland, 2009.

ALENCAR, M. de C. F.; ABREU, L. S. The gender: land relationship and sustainability: rupture of imaginary. In: EUROPEAN SOCIETY FOR RURAL SOCIOLOGY CONGRESS, 23., 2009. Conference Papers... Vaasa: Finland, 2009.

DEBACHERE, M. C. Problems in obtaining grey literature. IFL4 Journal, v. 21, n. 2, p. 9498, 1995. 
LAMINE, C.; BELLON, S. Conversion to organic farming: a multidimensional research object at the crossroads of agricultural and social sciences: a review. Agronomy for Sustainable Development, v. 29, n. 1, p. 97-112, 2009.

MARCO REFERENCIAL EM AGROECOLOGIA. Brasília: Embrapa Informação Tecnológica, 2006. 70 p.

ORGANIC EPRINTS. Disponível em: <http://orgprints.org>. Acesso em: 18 set. 2009.

PROJETO BASES CIENTÍFICAS E TECNOLÓGICAS PARA O DESENVOLVIMENTO DA AGRICULTURA ORGÂNICA NO BRASIL: Ciência e tecnologia para o desenvolvimento da agricultura orgânica. Disponível em:

$<$ http://www.macroprograma1.cnptia.embrapa.br/agriorg>. Acesso em: 04 set. 2009.

PROJETO TRANSIÇÃO AGROECOLÓGICA. Disponível em:

<http://www.macroprograma1.cnptia.embrapa.br/agroecologia>. Acesso em: 04 set. 2009.

WEZEL, A.; SOLDAT, V. A quantitative and qualitative historical analysis of the scientific discipline of agroecology. International Journal of Agricultural Sustanability, v. 7, n. 1, p. 3-18, 2009.

WEZEL, A. et al. Agroecology as a science, a movement and a practice: a review. Agronomy for Sustainable Development, v. 29, n. 4, Oct.-Dec., p. 503-516, 2009. 